NBER WORKING PAPER SERIES

\title{
INVISIBLE WOMEN: \\ ENTREPRENEURSHIP, INNOVATION AND FAMILY FIRMS IN FRANCE \\ DURING EARLY INDUSTRIALIZATION
}

\author{
B. Zorina Khan \\ Working Paper 20854 \\ http://www.nber.org/papers/w20854 \\ NATIONAL BUREAU OF ECONOMIC RESEARCH \\ 1050 Massachusetts Avenue \\ Cambridge, MA 02138 \\ January 2015
}

This research benefited a great deal from the assistance of Serge Bénoit, Esther Brubaker, Anne Chanteux, Christiane Demeulenaere-Douyère, Gérard Emptoz, Liliane Hilaire-Pérez, Phil Hoffman, Philippe Honigman, Naomi Lamoreaux, Tom Nicholas, Gilles Postel-Vinay, and the very helpful staff at the Société pour l'encouragement de l'industrie nationale, the Institut national de propriété industrielle, the Archives nationales, the Bibliothèque nationale de France, and the Conservatoire national des arts et métiers. The paper was completed while I was a National Fellow at the Hoover Institution. I am grateful for the support of the National Science Foundation, the Center for the Protection of Intellectual Property, and the IP2 Center at the Hoover Institution. All language translations are my own. Liability for errors is limited to the author. The views expressed herein are those of the author and do not necessarily reflect the views of the National Bureau of Economic Research.

NBER working papers are circulated for discussion and comment purposes. They have not been peerreviewed or been subject to the review by the NBER Board of Directors that accompanies official NBER publications.

(C) 2015 by B. Zorina Khan. All rights reserved. Short sections of text, not to exceed two paragraphs, may be quoted without explicit permission provided that full credit, including $(\mathcal{C}$ notice, is given to the source. 
Invisible Women: Entrepreneurship, Innovation and Family Firms in France during Early Industrialization

B. Zorina Khan

NBER Working Paper No. 20854

January 2015

JEL No. L2,L26,N13,N8,O14,O3

\begin{abstract}
Family firms are typically associated with negative characteristics, including lower tendencies towards innovation, a higher risk of failure, and inefficiencies deriving from nepotism among family members, criticisms which are even greater when the company is handed over to a female relative. Women in business have generally been presented as petty traders and passive investors, whose entrepreneurial activities were scarce because of such restrictions as limited human capital, culture, market imperfections, and institutional biases. The French economy has similarly been faulted for the prevalence of family firms during the nineteenth century, and for disincentives for the integration of women in the business sector. These issues are explored using an extensive sample of women who obtained patents and prizes at industrial exhibitions during early industrialization. The empirical evidence indicates that middle-class women in France were extensively engaged in entrepreneurship and innovation, and that their commercial efforts were enhanced by association with family firms. Their formerly invisible achievements suggest a more productive role for family-based enterprises, as a means of incorporating relatively disadvantaged groups into the market economy as managers and entrepreneurs.
\end{abstract}

B. Zorina Khan

9700 College Station

Bowdoin College

Brunswick, ME 04011

and NBER

bkhan@bowdoin.edu 


\section{INTRODUCTION}

"Some individuals had demanded a patent for the invention of an invisible woman."

-- The Law Library $(1834)^{1}$

Economic and social progress depends critically on the contributions of women to production and

productivity, both within the household and in formal business organizations. Scholars such as Jan de

Vries argue that industrialization was driven by an "industrious revolution" in which women redirected their attention from household labour towards market production. ${ }^{2}$ At the same time, researchers in Europe and the United States have suggested that women in earlier stages of economic development played a more central role in socioeconomic activities, relative to the increased specialization and the gender division of labour that characterized the advent of industrialization and Smithian economic growth. ${ }^{3}$ The introduction of mechanization and specialization did not necessarily benefit women, owing to the "proletarianization of families," an increase in gender-biased occupational segregation, and a fall in the labour force participation of married women. Cultural historians highlight social attitudes and legal norms that deprecated and decreased female participation in the market economy, with the corresponding retreat of urban middle class women during industrialization to a separate domestic sphere. ${ }^{4}$ Some claim, for instance, that the economic standing of women in France deterioriated in the period after the French Revolution, because guilds were no longer able to protect widows who inherited the skilled trades of their husbands, and there was an "increased hostility toward women in the marketplace."

\footnotetext{
${ }^{1}$ Napoleon was apparently incensed on learning that he could not refuse the application for a patent on the invisible woman. As a result, all patent grants after 1800 included a stipulation that the government did not guarantee such rights ("sans garantie du gouvernement"): "Government, by granting a patent without any previous examination, does not guarantee in any manner, either the priority, the merit, or the success of the invention." See The Law Library, Vol 4, J.S. Little, 1834, p. 5.

${ }^{2}$ De Vries, Jan, 'The Industrious Revolution and economic growth, 1650- 1830,' in Paul A. David and Mark Thomas, eds., The economic future in historical perspective. Oxford and New York: Oxford University Press, 2003, $43-71$.

${ }^{3}$ See Goldin, Claudia; Horrell, Sara and Jane Humphries, 'Women's labour force participation and the transition to the male-breadwinner family, 1790-1865,' Economic history review 48 (1995), 89- 117.

${ }^{4}$ Barker, Hannah, The Business of Women: Female Enterprise and Urban Development in Northern England, 17601830, New York: Oxford University Press, 2006, provides a nuanced assessment of the separate spheres argument.

${ }^{5}$ Lanza, Janine Marie, From wives to widows in early modern Paris: gender, economy, and law Aldershot, England ; Burlington, VT : Ashgate, c2007, p. 230. She also contends that "The moment when widows could become masters, accept risks, succeed or fail based on their resources and skill ... faded after the Revolution,"and "Notions of domesticity and the division between a private, female sphere and a public, male
} 
The prevalence of family firms among European enterprises comprises another contentious issue that is related to the role of women in business and the market economy. Business historians Alfred Chandler and David Landes contend that family firms tend to be inefficient modes of organizing economic activity, relative to the modern corporation that can take advantage of specialized management inputs and economies of scale. ${ }^{6}$ According to this perspective, family-run enterprises are typically undercapitalized, deficient in risk-taking and managerial abilities, and characterized by suboptimal scale and scope. These problems are exacerbated when the time arises for a handover of leadership from the original founder, to family members who might be less adept or knowledgeable about the business and industry. ${ }^{7}$ If unearned income reduces the probability of female economic activity, then the wives of successful entrepreneurs might not have acquired experience by participating in the family business, making them especially unprepared for taking over leadership roles in the event of death or retirement of the male entrepreneur. In some instances, lower investments were made in women's human capital because they were subject to gender discrimination within the family firm. ${ }^{8}$ Moreover, when cultural biasses implied that women were expected to participate in petty trading or economic activities that were linked to the household, or to avoid overt profit-maximization, their firms were less likely to be at the frontier of entrepreneurship and innovation. If women inherit ownership without the capacity to control

sphere coalesced into a powerful ideology of gender relations after the Revolution ... there was more ambivalence about women engaging in such public activities." For a detailed study of one guild, see Crowston, Clare Haru, Fabricating women: the seamstresses of Old Regime France, 1675-1791, Durham, NC : Duke University Press, 2001.

${ }^{6}$ Such issues are discussed in Carter, Edward et al. (eds), Enterprise and Entrepreneurs in Nineteenth- and Twentieth-Century France, Baltimore: Johns Hopkins University Press, 1976.

${ }^{7}$ Morck, Strangeland and Yeung (2000) find a decline in the performance of firms when leadership passes from the original founder to relatives, and dub this the "Canadian disease." Francisco Pérez-González uses the term "nepotism" as a synonym for family firms, and similarly argues that such firms are underperformers ("Inherited Control and Firm Performance," American Economic Review, vol. 96(5) 2006: 1559-1588. According to Cucculelli, Marco \& Micucci, Giacinto, ("Family succession and firm performance: Evidence from Italian family firms," Journal of Corporate Finance, Elsevier, vol. 14(1) 2008: 17-31), continued family control has a negative effect on firm performance. Nicholas, Tom, "Clogs to Clogs in Three Generations? Explaining Entrepreneurial Performance in Britain Since 1850." Journal of Economic History (September 1999), showed that those who had inherited firms were less financially successful.

${ }^{8}$ See Bessière, Céline, "Female and male domestic partners in wine-grape farms (Cognac, France): conjugal asymmetry and gender discrimination in family businesses," History of the Family, Vol. 19 Issue 3 2014: 341-357. (Women were subject to discrimination within their own families, and were not offered access to the skills and knowledge that would enable them to prosper at the head of the family firm.) Also, Wang, Calvin. "Daughter exclusion in family business succession: a review of the literature," Journal of family and economic issues 31.4 (2010): 475-484. 
the assets they have inherited, agency costs (such as the separation of entrepreneurial ownership and effective control over decisionmaking that Berle and Means had identified in the modern corporation) might be higher in female-owned family firms.

A more positive interpretation of the prevalence of family firms in all of these societies highlights their role in attenuating agency and transactions costs, as well as bridging market imperfections that inhibit productivity growth and economic progress. ${ }^{9}$ Family networks can compensate for market failure, through patronage, reputation, trust and social capital, the ability to monitor group members more effectively using cheaper enforcement mechanisms. Relational contracts may result in stronger incentives to adhere to agreements, comprising private commitment devices that enforce agreements and deter opportunism among market participants. ${ }^{10}$ Family members might also have stronger commitments to the survival of the enterprise, which might persuade them to bear greater variance in income and smooth consumption over a longer time period than a hired employee. Such networks could also reduce the risks inherent in entrepreneurship and innovation, and use "insider information" to identify and secure crucial inputs into productivity change and economic growth.

However, even if family firms played a productive role in American and European economic development, the possibility remains of a negative effect from female participation in this process. In the plethora of studies on business organizations, little systematic historical research has been directed to the specific link between women in business, the nature and consequences of their activities in family firms, and the extent of their entrepreneurship and innovation in early industrialization. ${ }^{11}$ Part of the difficulty in addressing these critical questions lies in the "hidden" nature of women's economic activities.

\footnotetext{
${ }^{9}$ For an excellent analysis of three successful family firms, see James, Harold, Family Capitalism: Wendels, Haniels, Falcks, and the Continental European Model, Cambridge : Harvard University Press, 2006.

${ }^{10}$ Naomi Lamoreaux's study of "insider lending" shows that elite investors in banks tended to be related to each other, and these owners directed a significant fraction of the loans in the bank to other insiders. She argues that, rather than unproductive "tunneling," relational links in the banking sector were an effective means of mobilizing capital. Insider lending facilitated risky investments in venture capital as industrialization got underway. My own research indicates that family ties were pervasive throughout all ranks of shareholders. Familial and other ties substituted for incomplete markets and helped to resolve problems that arise in the presence of such market imperfections as high risk and asymmetrical information. See Khan, B. Zorina, "Related Investing: Corporate Ownership and the Dynamics of Capital Mobilization," Working Paper, 2014.

${ }^{11}$ For a useful study of the records of a single insurance company in London, see Phillips, Nicola J., Women in Business, 1700-1850, London: Boydell \& Brewer, 2006.
} 
Quantitative studies are necessarily limited by existing data, leading to the result that as economic actors women have a visible presence largely as unskilled workers in factories, and to a lesser extent as passive investors in banks and manufacturing enterprises. According to a contemporary observer, in midnineteenth-century France "female employment was mostly, if not entirely, in the inferior grades of industry, requiring little skill." ${ }^{\prime 2}$ Historians have used case studies to provide ample insights into the contributions of women in petty trades, such as seamstresses, tavern or boarding-house owners, and as producers of items consumed by other women. ${ }^{13}$ Despite such valuable research, key aspects of the past and potential role of women in economic development await further empirical examination.

This article contributes to our understanding of these questions by exploring the role of "enterprising" women in France during the first half of the nineteenth century. The paper employs a conventional definition of entrepreneurship, since a significant fraction of productivity growth is associated with technological innovation and the management of risk inherent in new products, untried processes, and emerging industries. ${ }^{14}$ I first briefly discuss the laws and other institutions that enabled and constrained female inventive activity, entrepreneurship and innovation. The first part of the empirical analysis is directed towards an assessment of technological innovation, and examines approximately one thousand patents of invention that were granted to women between 1791 and 1855 . The second half

\footnotetext{
${ }^{12}$ George Grantham's study of farming households finds that women were typically involved in the farm work, but there was a low participation rate among the wives of merchants and tradesmen, and women in professional families. Middle-class women were subject to a gender-based division of labor, and avoided market pursuits as incompatible with their social status. (Grantham G., "Occupational, Marital, and Life-Cycle Determinants of Women's Labor Force Participation in Mid-Nineteenth-Century Rural France," Feminist Economics, 18(4) 2012: 97-119.) The first Society for the professional instruction of women was formed in 1862, its founding capital no more than 1250 francs, but such institutions quickly spread in France. Watherston dates the emergence of a skilled supply of female industrial workers in France from this period. Watherston, Edward James, The industrial employment of women in France compared with England: a paper read at the Social Science Congress, Cheltenham, 1878. London: Spottiswoode, c. 1879.

${ }^{13}$ Angélique du Coudray, an innovative midwife, provides an intriguing early example of entrepreneurial abilities. She secured patents in 1759 and 1767 for a "machine" or anatomically correct doll to teach obstetric methods. She was adept at securing patronage, and obtained a royal grant to travel the countryside to educate and train rural midwives. In May 1756 the prestigious all-male Academy of Surgery examined her invention and formally acknowledged their approval. See Gelbart, Nina R., The King's Midwife : A History and Mystery of Madame du Coudray, Berkeley : University of California Press, 1998.

${ }^{14}$ Several studies of women in business apply a Procrustean method of redefining entrepreneurship as any independent occupation, in order to capture typical economic activities by women. While petty traders and proprietors certainly make an important contribution to economic advances, this approach tends to underestimate or ignore the significant role of women in the upper ranks of business in the early stages of industrial growth.
} 
gauges women's contributions to commercialization and to managerial activities in innovative enterprises, by considering their participation in the Expositions publiques des produits de l'industrie française (hereafter the National Exposition of French Industry) and the Exposition universelle (Paris Universal Exposition) of 1855. These data illuminate the characteristics of numerous women who were active in managing and fostering growth in large, successful enterprises in nontraditional fields. They further offer unique insights into the family connections of the participants, and the effects of such connections on their tendencies towards entrepreneurship and innovation.

\section{INSTITUTIONS AND INNOVATION IN FRANCE}

"Laws and institutions must go hand in hand with the progress of the human mind." - Thomas Jefferson $(1816)^{15}$

Institutions, or the rules and standards that govern social and economic exchanges, may promote or inhibit the endeavours of all entrepreneurs, but women at times have faced different constraints and opportunities than their male counterparts. Indeed, some contemporary commentators seem to have overestimated the difficulties that female innovators faced in negotiating such institutions as the French patent system. ${ }^{16}$ French policies toward inventions and innovations developed from a system of politically-oriented privileges that dated from the middle of the sixteenth century. By the eighteenth century, state policies were based on an extensive, but somewhat arbitrary, array of rewards and incentives. Inventors or introducers and commercializers of inventions could benefit from titles, pensions that sometimes extended to spouses and offspring, loans, lump-sum grants, bounties or subsidies for production, exemptions from taxes, or monopoly grants in the form of exclusive privileges. In this welter

\footnotetext{
${ }^{15}$ Letter from Thomas Jefferson to Samuel Kercheval, July 12, 1816.

${ }^{16}$ According to JulieV. Daubié, La femme pauvre au XIXe siècle: Ouvrage couronné par l'Académie de Lyon, Guillaumin et Cie., 1866, the state was biased against women inventors and refused to grant them patents ("La justice impartiale et bienveillante de nos jurys d'exposition délivre, il est vrai, de nombreuses médailles ou mentions honorables aux femmes, mais l'État, non content de les expulser de ses écoles, leur refuse d'ordinaire, comme je l'ai fait remarquer au début de ce travail, les brevets d'invention qu'elles sollicitent.") The claim is inaccurate, since no one who paid the fees could be denied a patent, but if women at the time believed this was indeed the case, this might discourage their propensity to seek patents.
} 
of initiatives, some women were able to exploit their personal influence and connections to gain access to valuable commercial rights, even without any formal contributions to the discovery or innovation. ${ }^{17}$

This convoluted network of state policies toward inventors and innovators was revised but not completely removed in the era after the French Revolution. ${ }^{18}$ Patents were granted through a registration system, in which patent applications could not be refused as long as the fees were paid. The 1791 statute stipulated patent fees from 300 livres through 1500 livres, based on the declared term of the patent. After the reforms of 1844, fees fell but were still out of reach of the working class, ranging from 500 francs (\$100) for a five-year patent, 1,000 francs for a ten-year patent and 1,500 for a patent of fifteen years, payable in annual installments. Patentees could obtain a monopoly without any pretence at being the inventor, and patents of importation could be obtained for the introduction of inventions from overseas. If the patent right were assigned (sold off) the total fees for the entire term of the patent had to be paid upfront. For both buyer and seller, the legal and economic uncertainties associated with a registration system likely reduced the net expected value of trade. ${ }^{19}$ These uncertainties were all the greater because of the great difficulties that confronted anyone who wished to find out information about prior patents. ${ }^{20}$

The state remained involved in the discretionary promotion of invention and innovation through policies beyond the granting of patents. The inventor of a discovery of proven utility could choose

\footnotetext{
${ }^{17}$ See Levasseur, Emile, Histoire des classes ouvrières et de l'industrie en France avant 1789, Volume 2, Paris: A. Rousseau, 1901, p. 491, who testifies that "We see nobles and courtiers who have the ear of ministers associating with inventors and entrepreneurs. These connected individuals can more easily than the latter obtain patents for manufactures. Sometimes they put their own money in the business, sometimes they contribute only their influence, and they take their share in the profits." Influence was often independent of gender. In 1781, many influential women at court supported the request of M. le Chevalier de Gruyere for a privilege to manufacture a vegetablebased cosmetic rouge. Archives Nationales F12-992, No. 239 (Oct. 1781.) Liliane Hilaire-Perez refers to "La forte liaison qui existe en France au XVIIIe siècle entre technique et politique," (30) and argues that inventors were "plaidoyers (accumulant les preuves), car la technique n'est pas neutre, elle est porteuse des rêves, de revendications, d'ambitions calculées, d'utopies refondatrices et de politiques réalistes" (p. 34.)

${ }^{18}$ See Antoine Perpigna, The French Law and Practice of Patents for Inventions, Improvements, and Importations, Philadelphia: J. S. Littell (1852), p. 5. See also Perpigna’s Manuel des inventeurs et des brevetés, 8. éd. Paris: Chez l'auteur (1852.)

${ }^{19}$ Khan, B. Zorina, The Democratization of Invention: Patents and Copyrights in American Economic Development, Cambridge: NBER and Cambridge University Press, 2005.

${ }^{20}$ The Association of Inventors and Industrial Artisans was founded in 1849, and included numerous women, as well as husband and wife pairs, among its membership. They were especially concerned with improving access to information about patented inventions. Late in the nineteenth century patent lobbies were still protesting that "The patent right that French law places in the hands of our inventors is obsolete, imperfect and overpriced," and led to disadvantages for French inventors relative to other countries. Bulletin de la Société d'encouragement pour l'industrie nationale, Volume 98, pp. 668-670.
} 
between a patent or making a gift of the invention to the nation in exchange for an award from funds that were set aside for the encouragement of industry. National institutions such as the Société d'encouragement pour l'industrie nationale were established to promote mercantilists ends, and were emulated at both the regional and national levels. ${ }^{21}$ The Society consisted of eminent scientists and industrialists who awarded a number of medals each year to stimulate new discoveries in areas they considered to be worth pursuing, and also bestowed cash grants on deserving inventors and manufacturers. Committees often offered special commendation for innovations that promoted import substitution, or the replication of items that had been previously produced overseas. The award of assistance and pensions to inventors, innovators, and their families continued well into the nineteenth century. The most successful entrepreneurs tended to be well connected, and able to parlay their connections into privileged access to resources, rights and subsidies. ${ }^{22}$

The transition from the Ancien Regime system of privileges to the innovation policies of the nineteenth century was personified by the Marquise d'Argence, who was adroit in exploiting all available avenues to gain support for her endeavours. As an appointed lacemaker to the royal court, she devised (or claimed credit for) a machine that could spin flax into very fine thread that was useful for making delicate lace. She employed a number of young women in a factory-setting, ostensibly as a charitable project, to produce small amounts of thread that were then exhibited at expositions. The influential M. Molard, her representative before a committee of the Society for the Encouragement of National Industry, drew attention to her philanthropy, disabilities and advanced age, and the recent death of her husband. Attempts to elicit information from the Marquise about the technical process itself, however, received the

\footnotetext{
${ }^{21}$ Reports by industrial committees frequently gave out prizes for matching or duplicating the products of foreign producers, and for being successful in exporting to other countries. For instance, Mlle Manceau received awards from the Industrial Expositions and the Conservatory for Arts and Trades because her firm introduced in France a type of bonnet that was original to Italy. She was able to export the bonnets to other cities in Europe, the United States, and "remarkably" to Naples and Florence as well, possibly because of the lower price of her products.

${ }^{22}$ For an excellent discussion, see Hilaire-Perez, Liliane, L'invention technique au siècle des Lumières, Paris: Albin Michel, 2000.
} 
terse rejoinder, "It is my secret." ${ }^{23}$ The investigating Committee noted that it was not clear whether hers was an economical method, but still proceeded to include a notice on her behalf in the Society Bulletin, a prestigious achievement that undoubtedly boosted the market value of any invention that received this honour. The Marquise obtained a patent for her invention in 1818, and also patented an improvement the following year, but her charitable intentions did not extend to diffusion of the specifications, and she stipulated that the Patent Office should keep the information secret.

Wealthy women had additional advantages, because they could use their resources and connections to attenuate other aspects of the law that might hinder commercialization. ${ }^{24}$ As in England and the United States, in nineteenth-century France a married woman was subject to the rules of coverture, which vested her legal rights in her husband. By law, her husband controlled any property she owned or acquired, as well as her earnings and wealth. Married women were prohibited from entering into contracts, could not be sued, and could trade on their own account only if authorized by their husband. Some husbands granted their wives greater freedom, and authorized them to conduct exchanges on their own accord. In exceptional circumstances, the courts allowed married women to formally hold separate rights from their husbands, most commonly if it could be shown that her assets were at risk owing to his improvident behaviour. ${ }^{25}$ Courts were suspicious of such requests, however, because the revocation of coverture could lead to unscrupulous behaviour. Families could benefit from this separation of goods, if property could be sheltered from the claims of creditors, and this allowed the family unit to limit or avoid its liability.

Many historians argue that such laws did not have much of an impact, and some even propose that they might have had a positive effect, because they caused women to become familiar with the legal

\footnotetext{
${ }^{23}$ Bulletin de la Société d'encouragement pour l'industrie nationale (SEIN) vol. 9, May 1819, pp. 139-141. Mme Gobert even refused a gold medal for her improvements in varnish, because she similarly wanted to keep the process secret (p. 284.)

${ }^{24}$ Rich families could, for instance, create legal trusts that protected the assets of wives and daughters.

${ }^{25}$ Hardwick, Julie, Family business: litigation and the political economies of daily life in early modern France. Oxford; New York: Oxford University Press, 2009. A few of the patentees included information on their legal status as "sole traders," or "authorized by her husband," but it was possible that others were similarly circumstanced, so a systematic analysis of this variable is not possible.
} 
system. ${ }^{26}$ By contrast, previous research on the patterns for the United States indicated that coverture affected women's economic activities negatively: legal reforms that removed such laws altered the economic costs and benefits associated with women's involvement in commercial activity, in a way that increased inventive activity by female patentees. ${ }^{27}$ Similarly, women's entrepreneurship was likely constrained by their legal disability under French law. Commercial exploitation of patented innovations depended on the right to contract and to sue, to produce the invented article, to assign or purchase patent rights, and to prosecute infringers. Investors would be less inclined to offer funding if they were uncertain about their ability to enforce rights in loans, leading to far greater capital imperfections for women relative to men. The implications for women in business in France were sufficiently important that entire legal treatises were directed to the analysis of the law towards the wives of businessmen, including those who were active partners in the family firm. ${ }^{28}$

Women entrepreneurs certainly had to be prepared and able to enforce their rights, at times against companies with deeper pockets, as evidenced by patent litigation before the Civil Court of Paris to dispute the rights to a "very profitable invention." ${ }^{29}$ In May 1850 Madame Rubigny obtained a 15-year patent for a way to preserve vegetables, by boiling them with salt and aromatic herbs, and then drying them in the form of tablets, so they could be easily stored or transported, and reconstituted. It is relevant to note that the patent document states she was a sole trader who was separated from her husband, and had legally filed to have independent economic rights ("séparée de corps et de biens d'avec son mari").

\footnotetext{
${ }^{26}$ For instance, McMillan, James F., France and Women, 1789-1914, London: Routledge, 2000, considers such laws to be toothless and merely "theoretical."

${ }^{27}$ Matilda Joslyn Gage, "Woman as an Inventor," North American Review, vol. 136 (318) 1883: 488-89. "How does the law recognize women? ... It is only a little over a quarter of a century since the first state in this Union protected a married woman in the use of her own brain property. Is it any wonder then, that woman is not equal with man as an inventor," The Woman Inventor, vol. 1 (1) 1891.

${ }^{28}$ Bressolles, Paul, De la femme du commerçant : examen critique de la jurisprudence, Paris: Rousseau, 1888. Bressolles notes that the married businessman "often finds in his wife one of the most useful helpmeets ... who has an interest in seeing the firm prosper." (p. 14) However, if a married man wanted to obtain funding for a shop, he would find it difficult because it would be unclear if the shop were to be run by his wife, and a special authorization on her behalf would be just as inconvenient for the third party. Other traders always had to be alert to the prospect that the wife was an accomplice in her husband's attempt to defraud others.

${ }^{29}$ The lawsuit is reported in Malapeyre, L, Le technologiste ou archives du progrès de l'industrie française et étrangère, Paris, 1855: 58-62. The details of the testimony before the court are interesting, showing that Mme Rubigny was not cowed by the larger firm, and was spirited in asserting her rights to the invention.
} 
M. Masson's patent was granted in June 1850, one month later than Mme Rubigny's, but his invention was far more successful commercially. Chollet \& Company bought the rights to Masson's patent, and marketed the preserved vegetables in France and overseas, including the military and the colonies. Madame Rubigny complained of infringement on several occasions, with countersuits by the Chollet firm. The legal tribunal ruled in favour of the larger company but noted that, since she had only sold a modest amount of products, Rubigny should only pay 150 francs in damages plus costs. Rubigny appealed the judgement, but the final decision that came down in 1857 confirmed the ruling of the lower court.

Many women were investors themselves in the risky financial sector, drawing on funds that were available to them as entrepreneurs, widows, or members of wealthy families. Hoffman et al. find that women were frequent participants in credit markets in Paris, accounting for about 20 percent of transactions, but the majority of the market tended to feature trades by the upper income stratum, rather than artisans and ordinary workers. ${ }^{30}$ It is therefore noteworthy that in 1822,227 investors established the Savings Bank and Provident Society of Reims, for a working class cliente (farmhands, workers, artisans and domestic workers; the investors were not allowed to benefit from its operation). ${ }^{31}$ Twenty three of these shareholders (ten percent) were women; eight of them received income from businesses that their husbands had owned, while the rest were proprietors, merchants, and women of independent means. Wealthy women participated readily in financial markets as providers of liquidity. However, legal restrictions in the nineteenth century meant that married women and single women who were expected to marry would typically have lower access to external financing for their business investments. Family, whether as individuals or firms, was therefore all the more valuable as an institution that could compensate for these drawbacks.

\footnotetext{
${ }^{30}$ Hoffman, Philip T., Gilles Postel-Vinay and Jean-Laurent Rosenthal, "Private Credit Markets in Paris, 16901840," Journal of Economic History, vol. 52 (2) 1992: 293-306. See also Hoffman, Philip T., Gilles Postel-Vinay, et Jean-Laurent Rosenthal. Priceless Markets: The Political Economy of Credit in Paris, 1660-1870. New edition. University of Chicago Press, 2001.

31 "Caisse d'épargnes et de prévoyance de la ville de Reims;" see the Bulletin des lois du Royaume de France, De l'Imprimerie royale, 1823.
} 
The examination of patent records and data from commercial expositions enables us to adopt a more systematic empirical approach to the analysis of female entrepreneurs in the period of early industrialization. Nineteenth-century France was subject to great political and economic turmoil, comprising a risky business environment for all, but particularly so for female entrepreneurs. Women faced institutional constraints that impinged on their economic activities, but there is ample evidence that, while they might have been inhibited, they were able to draw on sufficient entrepreneurial initiatives and resources to engage in industrial enterprise and innovation. A major question relates to the implications of their business involvement for our understanding of the role of family firms in economic development.

\section{PATENTING AND TECHNOLOGICAL INNOVATION}

"Women have been scientists and warriors, but there have never been any female inventors." --Voltaire $(1829)^{32}$

Towards the end of the nineteenth century, Dr Antoine de Neuville voiced the common view that French women did not have as much of the inventive faculty as Americans, and the roster of mechanical patents that a woman filed in France was likely for inventions that had been devised by employees of her firm: "There is no need to make mention here of patents for mechanical inventions, taken on behalf of the woman when she runs a trading house or factory or workshop. It is easy to see, in this case, the idea is due to a manager, a worker; ...Now, where we find the hand and mind of the woman herself is in the patented manufacturing of new corsets." 33 Was de Neuville correct in his claim that his compatriots were not inventive, and an unknown number of female patentees had obtained property rights in inventions that had been created by others?

\footnotetext{
32 "On a vu des femmes très savantes comme il en fut de guerrières; mais il n'y en a jamais eu d'inventrices." Voltaire (1829), Dictionnaire philosophique, Voltaire, éd. Lequien, 1829, tome 4, article « Femme », p. 354. ${ }^{33}$ De Neuville, A, "Le génie de l'invention chez les femmes," La Revue mondiale: ancienne Revue des revues, 1900, 184-190 (p. 187). (189) Similarly M. Destable made a speech before the Appellate Court of Rouen, in which he compared the professional progress of women in France and the United States, to the detriment of French accomplishments, arguing that the "New World is the classical land of the new woman" (p. 14). Destable, M, "De l'évolution féministe comparée en France et en Amerique," 17 October 1898, Rouen: LeCerf, 1899. See also Jean Baptiste André Godin, J. Pascaly, "Femmes Inventeurs," Le Devoir: revue des questions sociales, Volume 24, 1900, p. 227-228. French reforms in the laws towards patents were in part influenced by the United States, and many commentators were similarly impressed by the inventive abilities of American men and women, attributing their skills in part to the favourable legal and patent systems.
} 
French patent laws were directed towards raising revenues for the state, and towards creating incentives for commercialization, rather than for new and useful inventions. Patents of importation could be obtained for foreign inventions, to enhance their introduction and diffusion in the French market. Women could patent ideas that were the product of their employees or relatives. A husband or other family member might list a woman on the patent document in order to avoid legal controversies and probates in the event of his demise, but men might also legally patent an invention that was created by a woman. As such, patent statistics in the French case (as in any registration system with high fees) provide an index of entrepreneurship and commercialization, rather than inventive activity per se. And it is indeed plausible that women (whether French or American) were more likely to file "autonomous" patents in "traditional areas" in which they held a comparative advantage, such as apparel and household items; whereas inventions in more technical "nontraditional" areas had a higher probability of deriving from the efforts of male associates. In any event, what seems most striking about de Neuville's remarks is his implied assumption that female patenting and management of industrial enterprises were the norm. For, regardless of the truth of his claims, both the filing of patents and the ownership of firms testify to female entrepreneurial activities that are worth further examination.

Figure 1 shows the time series of patents that were obtained by women in France, relative to the national total. Between 1791 and 1855, French women obtained approximately one thousand patents. This total was far in excess of the 53 that their American counterparts were granted in the same period, despite the much lower fees and the streamlined application process in the United States. ${ }^{34}$ Women filed 2.4 percent of all French patents in this era, a fraction that was double the corresponding statistic for the United States even at the end of the century. The proportion of patents that were issued to women increased substantially after the legal reforms and cheaper patents of 1844 , rising from 1.6 percent to 3.0

\footnotetext{
${ }^{34}$ This supports the notion that many French patents were titled to women who were not the creator of the idea. U.S. laws allowed patents to issue only to the "first and true inventor." However, "French law does not require that the person applying for a patent prove that he is his inventor: it protects the invention without caring about the inventor. As a result, when inventor dies before taking a patent, the right to take out a patent is available to his heirs, and it can be issued either in their name or in the name of the deceased." Clunet, Edouard, Journal du droit international privé et de la jurisprudence compare, Paris: Marchal Billard, 1879, p. 560.
} 
percent of the total in France. The Figure illustrates that the cyclical patterns of male and female patenting were somewhat similar, most notably declining after the political and economic turmoil associated with the "February Revolution" of 1848. At the same time, the patterns for female filing exhibit significantly lower variance over this period, and a two-sample F-test confirms the visual impression from the time series. This suggests that women who obtained these patents were partially insulated from the shocks that influenced upturns and downturns in male patenting.

Table 1 indicates that the majority of women's patenting was in traditional fields such as household items, food, and apparel, and closer examination of other evidence indicates that many of these patents covered improvements that women had devised themselves. For instance, Mme Marie Breton, a Parisian midwife, obtained patents in 1824 and 1826 for a baby's feeding bottle and artificial nipples, for which she sought and obtained favourable notice from pharmacists and the Royal Academy of Medicine. A firm was established to manufacture and market her products, and she won numerous medals at exhibitions. Patents that women similarly received for various types of hats, shoes and corsets increased over time. Women filed 57 patents for corsets, which comprised a disproportionately high 10.6 percent of all 538 corset inventions that were granted between 1791 and 1855 . The prominent textile industry attracted the same proportion of patents by men and women alike, although its relative importance in the patent records for women declines over time. As might be expected, men were much more likely to patent machines, engines, and transportation inventions, and improvements in the iron and metal industries, that required more technical experience and human capital.

The biographies of patentees who could be traced are obviously biassed towards successful entrepreneurs but it is significant that, contrary to common perceptions, many of these women were associated with innovative industrial enterprises. Amélie de Dietrich, a "maîtresse de forge" from a wealthy aristocratic background, was the owner of five patents for iron railroads and bridges, that most likely covered inventions created by her workers. The Dietrich firm had been prominent in Alsace since the seventeenth century as producers of cast iron. Mme de Dietrich's husband died in 1806, leaving his 30-year old widow with a family firm that was in debt. She completely reorganized the enterprise, now 
called Veuve (widow) de Dietrich \& Fils, and shifted the focus of the product line to machine goods, stoves, bridges and railroads. Regardless of their origin, the patents indicate that the firm's production methods were technologically innovative. The company expanded and acquired other factories, and Mme de Dietrich is credited with the introduction of decorative designs in industrial products. By the time of her death in 1855, she left to her sons one of the most prominent enterprises in the region, that would continue to flourish for another two centuries. ${ }^{35}$

Women were experienced in the book industry, as booksellers, writers, printers and publishers, and this is reflected in the patent records. ${ }^{36}$ Eugénie Niboyet (1796-1883), the grand-daughter of physicist Lesage, and a writer who was a notable figure in the struggle for women's rights, obtained an 1838 patent for indelible printing ink. Eulalie Lebel (1809-1898) provides another telling case study of the motivations and direction of female entrepreneurial efforts. ${ }^{37}$ She was the only daughter of JacquesAuguste Lebel, a printer, and she married François-Marie Bouasse, an employee in a printing house. Her husband abandoned her and their two children, and she was responsible for paying his extensive debts. This motivated her to found her own printing house in 1845 , clearly drawing on skills and experience that had been gained within the family. Eulalie Bouasse's career in printing religious engravings and publishing, in association with her sons Henri and Emile, lasted until $1863 .{ }^{38}$ Between 1849 and 1855 ,

\footnotetext{
${ }^{35}$ The firm of Veuve Mermilliod and Son comprised yet another major family firm that employed more than a hundred workers, and lasted for over a century. The widow and her three sons ran a cutlery manufacturing business, inherited from the father, and Mme Mermilliod and her eldest son obtained a patent of addition for an 1842 system of knife-making machinery. The sons had complementary talents: Eugène, the co-patentee with his mother, was very innovative; whereas his brother Charles was an experienced manager, and several cousins also joined the firm. See La coutellerie depuis l'origine jusqu'à nos jours: La fabrication de la coutellerie, Paris, 1898.

${ }^{36}$ See Arbour, Roméo, Dictionnaire des femmes libraires en France, 1470-1870, Paris: Librairie Droz, 2003. This work has 6424 entries. During the Ancien Regime, such occupations were open to women only as widows whose husbands had authorized their wives to inherit their positions in order to sustain the family. However, after the Revolution, these positions were made available to all women, and by 1870 they held a third of all bookseller's licences.

${ }^{37}$ Similarly, two patents were granted in 1854 and 1855 to the widow Berger-Levrault and her son, for ruling machines. Maison Berger-Levrault is a prestigious French publishing company, with origins in the fifteenth century, which still exists today. Caroline Levrault took over the business on the death of her husband, and successfully ran it for almost three decades, aided by her children and their spouses. When Caroline died in 1850, her daughter Eleanor, widow of Pierre-Frédéric Berger, took over the business, and introduced modern new metal presses. The company participated in the Universal Exhibition of 1855, and won medals several times at other events.

${ }^{38}$ The business relationship with her older son was not entirely amicable, highlighting some of the problems with family firms relative to impersonal corporations. For instance, he wanted to expand beyond the religious motif of
} 
Mme Bouasse-Lebel and Henri obtained four patents, related to making prints on different types of materials. Maison Bouasse-Lebel frequently entered their products at expositions, and received domestic and international accolades for their religious engravings, chromos, and albums. ${ }^{39}$

Patentees of items that were controlled by the French government, such as printing presses and firearms, had to be especially adept at maintaining quality and negotiating with state bureaucrats. The Gévelot company was founded by Joseph-Marie Gévelot (1786-1843), who held two patents. When he died, his widow Joséphine and her teenage son Jules inherited the firm, which became world-famous for the quality of its firearms. They manufactured cartridges and fuses in their Paris location, and gunpowder at Issy, just outside the city. Joséphine Gévelot partnered with François Lemaire, a businessman, to obtain a patent for firearm cartridges in 1845 . Her company was associated with eight more patents in the following decade, including one for an invention from Italy. At the Paris exhibition of 1844, the jury awarded a bronze medal, noting that "Mme Veuve Gévelot has perfected the various details of manufacturing, and her products are always very much in demand in the market. The house of Gévelot produced well in 1839 [before her husband's death]; it produces a great deal better in 1844."

The patent records signal growing sophistication over time among women at both invention and innovation. As the summary statistics indicate, the majority of male patentees obtained patents that were shorter than the full term of 15 years, but the average term was significantly different for women's patents. ${ }^{41}$ In the period before 1835 , half of the patents that women filed were short five-year instruments, which were cheaper, and less risky investments if the applicant were uncertain about the value of the invention. However, over time that pattern changed significantly, towards full-term patents,

their product line that was his mother's trademark. He left to form his own company in 1864, entering into competition with the firm that his brother Emile now headed. Details of litigation between them are available in Rapport dans une contestation entre Mme Ve Bouasse-Lebel, demanderesse, et M. Bouasse-Lebel, défendeur. A MM. les Président et juges composant le Tribunal de commerce de la Seine, Paris, 1869; with an appeal in 1871.

${ }^{39}$ Maison Bouasse-Lebel received medals in London 1854, Paris 1855 et 1867, and also exhibited at the Centennial in Philadelphia 1876. Their engravings are highly-prized by collectors today.

${ }^{40}$ See Rapport du Jury central, Paris: Imprimerie de Fain et Thunot, 1844, p. 607.

${ }^{41}$ The term comprised a maximum duration, since the patent rights were lost if the patentee failed to maintain the annual payments. Overly-optimistic patentees found it was wiser to let the patent right lapse before the end of the term. Mlle Elisa Caroline Edwards from Rouen took out a patent of 15 years in 1836, for catching fish, but she let it expire three years later. Similarly, M. Lize and his wife let their patent of five years for designing carpets lapse after two years, when they failed to pay up the required annual fee. 
and additions that incorporated improvements to the original invention. This shift was in part due to a correspondence between higher-quality patents and participation in firms. The fraction of patents to women in noncommercial occupations such as midwives or teachers fell from 43.2 percent before 1835 , to 13.4 percent after 1850 . Instead, patents were much more likely to issue to women in manufacturing, which increased markedly over time, to almost two-thirds of all filings. Entrepreneurship also requires flexibility to meet new opportunities, and this characteristic can be observed in several women inventors. For instance, the Joly sisters obtained a full-term patent on corsets, and listed themselves as corset-makers in 1848; however, by 1853 the sisters were manufacturing envelopes that were secure enough to use for confidential business transactions, for which they had obtained another patent.

Some researchers today conclude that women are underrepresented in the managerial and entrepreneurial professions because of a lack of attention and training from their fathers. It is impossible to test this hypothesis with these data, but there are several examples of daughters who were clearly influenced by their fathers. The patent records provide useful examples of the likely influence of parents on the entrepreneurial tendencies of their daughters. Rosa Martres's patents noted that she was the daughter of the famous Antoine Gazy-Cazalat, a physicist, engineer and inventor with some 44 patents to his credit through 1855. Mme Martres herself received seven patents for improvements in coffee-makers, an extremely popular subject for inventors of the day. ${ }^{42}$ The Houels, mother and daughter, provide insights into the relationship between entrepreneurial mothers and their daughters. Mme Houel received a favourable citation from the jury at the 1823 exposition, for making paints that dried quickly and did not have a strong scent, which could be used on a wide array of materials ranging from wood to metal. In 1839 , her daughter exhibited improvements on this paint, which led the jury to grant her a bronze medal.

\footnotetext{
${ }^{42}$ Mme Vassieux, another women inventor, was one of the most successful of the patentees in this area, and her coffeemaker design was still being used and adapted many decades after the expiration of her six patent from the 1840s. The Cheradame father and daughter provide another example of patenting running in the family. Antoine Cheradame received some six patents between 1828 and 1837, primarily for inventions to increase the brightness of lamps while maintain their costs. His daughter Pauline obtained her first patent in 1846, and subsequently filed some nine patents for inventions in the following decade, mainly for making artificial flowers.
} 
In short, women might not have had significant exposure to machine trades and training (only one declared herself to be a "mécanicienne"), but they were still able to engage in industrial management and entrepreneurship, drawing on experience they had obtained in collaboration with parents, siblings or husbands. In addition, part of the credit for their success in running family firms undoubtedly owed to the loyalty of their skilled employees. ${ }^{43}$ Female participation within family enterprises also allowed them to engage in transactions that would have been less likely in the marketplace, and to bypass the genderbiassed laws of property and contract that restricted their outside activities. Such firms were disproportionately located in Paris, perhaps because those outside the capital lacked the networks that male inventors possessed, which allowed them to overcome the transactions costs of engaging in trades over longer distances. Many parties who did operate outside Paris engaged the services of agents to secure property rights in inventions, ranging from informal representation by relatives, to specialized patent attorneys. ${ }^{44}$

The number of patents per person provides an indicator of professionalism in patenting activity. The patterns for multiple patenting in Table 2 are significantly different across countries, and these results are especially informative. In the U.S. two-thirds of women's patents were to inventors who never filed a second patent, whereas almost three-quarters of French patents (including improvements) were for multiple patents. For instance, Sophie-Geneviève Mercier obtained 15 patents between 1842 and 1855 , the majority for various inventions to treat laundry, and two for cleaning cutlery. Given the nontrivial patent fees, these inventions were likely to have been commercially successful, but Mercier comprises

\footnotetext{
${ }^{43}$ The firm of Debuchy was notable for the quality of its workforce of almost 300 workers. The foreman, Auguste Flaveau, worked for the company from 1824 for more than three decades and himself received an award for his productivity. Mme Veuve Désirée Debuchy inherited a prosperous textile-making enterprise in Tourcoing (Nord) which, under the ownership of her husband, won medals each year from 1827 up to the time of his death. Under her management, the juries at the 1849 and 1855 exhibitions rewarded the products' good taste, low prices, their commercial success and their competitiveness with English goods. (Rapports du jury mixte international: Exposition Universelle de 1855, Volume 2, Paris, 1856, p. 321.) The sons continued the tradition of earning awards for the excellence and affordability of its products, until the company was dissolved in 1886 (Le Jacquard: journal de l'industrie lainière, 1886, p. 173.)

${ }^{44}$ Many patentees used the services of such eminent (and expensive) attorneys as Delagrand and Antoine Perpigna, who had an international reputation.
} 
one of the "invisible women" about whom no further sources are available to illuminate her contributions to technological innovation and enterprise.

The overall patterns for female patentees indicate that such professional patenting was associated with greater ownership of manufacturing companies and other related businesses. The three-hundredyear old firm of Wendel in the Moselle region of France has been regarded as an icon of French-style "family capitalism," expanding in the nineteenth-century to become of the industrial leaders in the European iron industry. ${ }^{45}$ The matriarch of the family business, Joséphine de Wendel (1804-1851), listed her occupation as "iron-works proprietor," when she obtained patents in 1839, 1847, and 1851, for improvements in coke-fired blast furnaces and iron products. The company maintained its position by keeping up with technological innovations, both from its own improvements and from overseas, including the importation of skilled workers from England who could reveal the latest industrial techniques. ${ }^{46}$

Women were active on both sides of the market for patent rights, as buyers and sellers, or as recipients of titles from relatives. The grant of a patent often led to the establishment of factories to commercialize the invention or product. ${ }^{47}$ For example, a machine patent was granted to Mlle Gervais in 1834, and the same year a company was floated to exploit her inventions, in partnership with M. Raynal, a rentier. Mlle Caroline-Françoise Lukkow assigned the rights to her orthopedic corset invention even before the patent was granted, to Auguste Daubian, a medical doctor, indicating a strong belief in the commercial value of the improvement. However, the majority of contracts that could be traced involved

\footnotetext{
${ }^{45}$ For more details on the history of this company, refer to James, Harold, Family Capitalism: Wendels, Haniels, Falcks, and the Continental European Model, Cambridge : Harvard University Press, 2006. The women of the Wendel industrial dynasty ruthlessly manipulated the inheritance portions of the children in order to maintain a company that was based on the "spirit of preservation and of family" (quoted on p. 66). When the company passed on to the younger Wendels, the older women in family contributed over 38 million francs to the capitalization and allowed just 20 percent of the profits to be retained by the two male relatives who managed the operation.

${ }^{46}$ For a similar example, see Mme la Marquise de Raincourt (1776-1864), propriétaire des forges de Fallon (HauteSaône), who obtained a patent in 1842 for an iron furnace, with a term of five years. The agent for the patent application was LeGrand, the manager of the forge. Mme de Raincourt took over the iron works after her husband died in 1832. The year after filing the patent, she obtained additional concessions for iron mines in Doubs and Ghammost.

${ }^{47}$ Marie Larguier's application for a 10-year patent for the refining of suphur in match production includes additional personal information, noting that she was 27 years old and from the town of Manzat in Puy-de-Dôme, with the occupation of "manufacturer of matches". She was the wife of Jacques-Antoine Larguier, and together they had founded a workshop in the neighbouring town of Clermont-Ferrant to manufacture the "chemical matches" that she had patented.
} 
married or widowed parties. M. Guicheux's patent of 1836 was assigned jointly to the Guérins (husband and wife), who formed a partnership limited by shares to exploit the patent, under the name of Guérin, femme Guérin et compagnie. By contrast, the notarial records in 1851 include the patentee Joseph Barbier and his wife (a rentière), whose company was dissolved after their marriage broke up. ${ }^{48}$

Innovative women were also prepared to defend their business interests to the fullest extent, whether as assignees or against them. Mme Anne-Charlotte Matelin assigned her 1836 patent to M. Brisset with the stipulation that he should not reassign it to any other party, and also required that his improvement patent had to be taken out in her name. Mme Mougniard was a manufacturer of candles made of spermaceti mixed with wax, who purchased the full assignment rights to a patent for candlemaking that Heinrich Danker had filed in 1822. She entered into litigation with M. Chapelle for infringement of her patent, and also indicted Danker for not enforcing her rights as the exclusive assignee, requesting all possible legal remedies, including damages, an injunction, and confiscation of the allegedly infringing products. Chapelle countered that Mme Mougniard had unfairly tarnished his reputation and paralyzed his business, through notices she had advertised in the newspapers, through the seizure of his goods, and her prosecution in the courts. He further charged that the patent was invalid, and requested that the court overturn her assignment, with compensation for his losses. These legal proceedings make it quite clear that she was acting on her own account and protecting her own interests.

Table 3 investigates the determinants of the degree of professional patenting, as a proxy for greater investments in technological innovation. Location in Paris increased the amount of investments in property rights in inventions and discoveries. The regressions confirm that greater numbers of patents were linked to the ownership of manufacturing firms. The numbers of patents were not significantly related to the industrial sector, although the miscellaneous sector was less likely than the "nontraditional" fields to be associated with higher numbers of patents. As might be expected, "petty" inventions protected with five-year terms were negatively related to professional patenting. Perhaps the most

\footnotetext{
${ }^{48}$ Fonds : MC Cote : ET/LXXXV/185103-r25, Numéro : 43053; Objet : dissolution de societe d'exploitation de brevet de freinage des wagons.
} 
intriguing results from the regression are related to marital status. The dummy variables represent the values for women who were (or had been) married, relative to the excluded variable, single women. The coefficients for the interaction between marital status and manufacturing suggest that wives or widows associated with manufacturing firms were significantly more likely to have made larger investments in patented inventions. This finding is consistent with the idea that patenting by women was enhanced by their participation in family firms.

\title{
IV. PATTERNS OF ENTREPRENEURSHIP AND INNOVATION
}

\author{
"It is need in the market that causes industrial progress. When \\ a need manifests itself, everyone starts working to develop a \\ solution." -Universal Exposition, $1855^{49}$
}

The conventional view of women in the nineteenth century is that they were active participants in the market economy, but as "penny capitalists" who were sole proprietors or the owners of small retail establishments that catered to the consumption needs of other women and their families. ${ }^{50}$ Middle-class women, some have argued, were bound by a cultural bias against market-oriented pursuits. The patent records offered a valuable perspective on such questions, for they provided ample evidence of women who paid the significant fees required to secure property rights, many of whom were doing so in order to promote innovation in family firms that they co-owned and managed. During this era women in France were unable to acquire managerial or innovative human capital through formal schooling or external apprenticeships, but family firms ideally offered an environment that could compensate for external institutional disadvantages. If women were actually active participants in the business, especially while their male relatives were alive, then transitions to their leadership would be less disruptive, and greater longevity of family firms would be more likely.

\footnotetext{
${ }^{49}$ Rapport sur l'exposition universelle de 1855 présenté à l'Empereur, Paris: 1856, p.148.

${ }^{50}$ See Craig, Beatrice, "Petites bourgeoises and penny capitalists: women in retail in the Lille area during the nineteenth century," Enterprise and Society, vol. 2 (2) 2001:198-224. Craig uses tax records, which will tend to miss women who worked in family firms. She finds that women in the middle classes of Lille and Tourcoing did not conform to the separate spheres model; however, their work was gender-biassed and, in 1852, these records suggest they headed about four percent of tax-paying industrial enterprises.
} 
This section offers a perspective on such issues by assessing women's participation in commercialization, through their involvement in national exhibitions in France. These data make visible the entrepreneurial efforts of women over time, in a highly competitive environment. The French Exhibitions of National Industry were intended to provide a stimulus to domestic production and industrialization, and were the inspiration for subsequent international expositions such as the Paris Universal Exposition of 1855. Table 4 illustrates that these events expanded in scope and objectives between 1798 and 1849. The numbers of exhibitors, size of the display space, and the amount of prizes offered increased steadily over this period, as did the popularity of the event with visitors. "Grade inflation" in the number of awards per exhibitor is evident, and by the end of the period over 80 percent of the entries would receive a medal or honourable mention. The proportion of these accolades that were bestowed on women fell over time, although their propensity to get medals was higher than the propensity to obtain simple mentions, suggesting a higher average quality for female contributions.

Table 5 shows the patterns of female participation in the exhibitions in terms of marital status. The vast majority of awards that both men and women received at the industrial exhibitions went to businesses and, in particular, to manufacturers. It is useful to compare the statistics here with the patent records, and to note that women's efforts at exhibitions were directed, to an even greater extent than their patenting, towards commercial marketing for firms. Among patent holders, 47.4 percent were occupied in manufacturing, compared to 70.5 percent of those who received some form of mention at the industrial fairs. The percentage of married women in manufacturing firms or with another person (collaborators) was somewhat lower, in part because family firms would typically have been listed under the husband's name. We know this was indeed often the case, after their "emergence" in the records as widows makes their previous efforts as wives more visible. Widows, who inherited businesses that had been founded or managed by their husbands, tended to be the least likely to offer exhibits in the realm of traditionally female industries, such as apparel and household items; by contrast, 18.1 percent of their awards were in technical fields, and a third were in the textile industry. 
Table 6 reports an analysis of factors that influenced persistence, or continued recognition for industrial excellence among women entrepreneurs. A few single women were in business with relatives, but in general marriage and widowhood show a stronger relationship with family firms. ${ }^{51}$ Over 34 percent of awards accrued to married women, and a further 40 percent of awards went to widows. A large number of these widows were representing firms in which they had been active prior to the bequest. This can be seen in the case of men who appeared in the exhibition records, and who were followed immediately after their death by widows responsible for product improvements or innovations of sufficiently high value that they were awarded medals. ${ }^{52}$ Each award was unique to a recipient for any specific year, so their frequency count indicates the degree of persistence over time in the quality of innovations. Manufacturing firms that were associated with married women and widows were significantly likely to receive greater numbers of awards, suggesting that such family firms were continuing to participate at a high level in the national exhibitions over the course of several years. Regressions with interactions for patentee status (not reported) support the notion that such women were also more involved in sustained investments in commercialization as patent holders.

Some of the reports reveal more systematic research and development among multiple award winners. A combination of scientific expertise and entrepreneurial acumen is rare in any era, but we can point to at least two such examples among French women. Marguerite-Marie Degrand made valuable contributions to scientific and industrial advance, associated with the international quest to replicate

\footnotetext{
${ }^{51}$ The Henriot Brother, Sister \& Company from Reims made flannel and fleece textiles that juries at various exhibitions regarded as consistently of a superb quality. Their products received numerous accolades and medals, including a coveted gold medal at the Paris Expositions of 1827 and 1834, which were awarded to the son and his widowed mother. The firm of Lespermont Brothers \& Sister manufactured paper and they jointly obtained a patent for a machine press that was more economical.

${ }^{52}$.Numerous examples of women actively engaging in innovations that built on their husbands' success are visible in the reports of the juries for expositions. Mme Veuve Ladrière, was the widow of Ferdinand, who had obtained a silver medal in 1819 , for high-quality fabrics. The factory under her management at Aisne employee one thousand five hundred workers. The jury at the next exhibition in 1823 bestowed a rare gold medal on her products, noting that she had made "remarkable progress." The jury similarly noted that the great improvements Mme. Veuve Decoudun and her foreman had made to boilers for public laundries. Her husband had been very successful, but her innovations in 1849 comprised the biggest advance in the industry so far. They concluded that she had maintained the worthy reputation that her husband had acquired. Rapport du Jury Central sur les Produits de l'Agriculture et de l'Industrie, Paris: Impr. Nationale, 1824 and 1850.
} 
crucible steel from Damascus. ${ }^{53}$ Elisabeth Gervais was also renowned because of her research and development into oenology, which resulted in two patents in 1818 and 1820 for apparatuses to condense the vapours in winemaking. Mlle Gervais owned a vineyard in Montpellier, and her experiments to improve the quality of wines, some claim, were inspired by her brother, Jean-Antoine Gervais. The Bordeaux Royal Academy gave a prize in 1822 to a researcher who disproved her findings; nevertheless, this method was adopted and refined by several other chemists and researchers, and proved to be highly successful commercially. She opened one company in Paris to market the patent rights for specific districts, and a second in Montpellier that was under the management of her brother. Despite the quibbling among contemporary scientists about the originality and value of the invention, the sale of these rights to practicing winemakers earned her "considerable profits."

These data offer unique insights into the experience of entrepreneurs who demonstrated exceptional initiative and business acumen. One of these, Mary Louise Sensitive Armfield (1793-1871), was the daughter of Thomas Armfield, a manufacturer who immigrated to France from Birmingham, and established a textile spinning factory in the Indre-Loire region in 1806. Mary married her father's business partner in 1814, and participated in the running of the business. Some sources claim that she did so only after being widowed; however, the exhibition evidence clearly identifies her as the responsible party well before this period. On the death of her husband in 1828, she took sole control of the company, and managed it for over four decades until the age of 68. The firm grew rapidly, introduced mechanical steam-driven processes, and was able to produce high-quality products in large quantities, at competitive prices. The enterprise, Toiles de Mayenne, was technologically innovative, and earned silver medals at the Exposition of French Industry in 1823 and 1827, which the judges opined were "distinctions that were

\footnotetext{
${ }^{53}$ The renowned English chemists, Stoddart and Faraday, published their findings steel alloys in 1820. But their claim to priority was contested by the French, because of the efforts of Mme Marguerite-Marie Degrand and her husband. In 1819, Mme Degrand received an honourable mention for her stainless steel cutlery, and a medal in 1823 for her contributions to the art of making metal products that rivalled those of Damascus. The Society for the Encouragement of National Industry bestowed on her its Grand Medal, and she was one of its members in 1824. For further information, see Daumalin, Xavier and Henri Tachoire, "Un couple d'innovateurs marseillais et la Société d'encouragement pour l'industrie nationale : les époux Degrand-Gurgey."

${ }^{54}$ See the Bulletin, Société royale d'agriculture, arts et commerce des Pyrénées Orientales, Perpignan: Tastu père et fils., 1820, p. 207.
} 
well-deserved." These merits were sustained, and thirty years later accolades were still being bestowed. The Société industrielle et agricole d'Angers awarded Armfield's firm medals and cash prizes on several occasions in the 1850s to recognize the sustained quality of its output and its affordable prices.

Toiles de Mayenne illustrates the importance of nontechnological innovations in the success of business enterprises, and in particular the introduction of "family-friendly" management practices that improved the conditions of the labour force. The company operated on a scale that was unusual at the time, and employed hundreds of (primarily women) workers (760 in 1812). During Mary Armfield's tenure, the firm established free accommodations for workers in an autonomous village; each family was assigned two private rooms, a garden, and a communal room to share with other workers. The company also owned a farm that produced fresh healthy food for the employees, and the workers' children were freely educated at a company school, with the hours corresponding to those of the factory. A contemporary guide to the district noted that Mme Armfield's factory was "a source of good, not only for the owner, but for the entire population." 55

\section{CONCLUSIONS} "This business model... melds entrepreneurial passion with a long
family tradition and a culture of performance and responsibility."
--Wendel Company (1704-2014)

The French economy has generally been faulted for its relative delay in industrialization, which some have linked to cultural attitudes and too great a dependence on family firms. The issue is not entirely of historical interest, since family firms are pervasive not only in the past, but also in today's developing economies. Given this prevalence of such organizations throughout time and place, it is important to understand the dynamics within family firms. Moreover, it is commonly acknowledged that economic development depends critically on the integration of women into the market economy, despite the institutional inhibitions to their full participation. As a recent survey of research concludes, "much can be

\footnotetext{
${ }^{55}$ Reichard, Heinrich August Ottokar, Guide classique du voyageur en France, dans les Pays-Bas et en Hollande, Audin, 1827, p. 168.

${ }^{56}$ See the firm's website: http://www.wendelgroup.com/fr/300-ans-dhistoire 16.html.
} 
learned by taking seriously the 'family' part of 'family firms." period when industrialization was getting underway, because of the lack of historical information on both firms and their managers, especially when those managers included wives, daughters, or widows.

The information on French patentees and industrial exhibits are clearly not representative of all female market participants, who typically would have been sole proprietors or partners in small-scale endeavours related to their skills at sewing or other household tasks. However, the sample of exhibitors and patentees in nineteenth-century France is valuable because it disproves the notion that entrepreneurial women were the exception. These women, when made visible, introduced innovations, took risks, were active in commercialization and competition, and managed large-scale enterprises, often with hundreds of employees and significant capitalization. Their experience allows us to place the numerous case studies from scantier sources in context, and to draw more general inferences regarding the role of women in entrepreneurship and economic development. In particular, the results from this study suggest that family firms can offer a conduit for the skills and abilities of individuals who are relatively disadvantaged members of society.

Social and economic progress are promoted by flexible rules and standards, and in particular by institutions that can adjust to compensate for drawbacks in other realms of society. As in many other countries, married women in France were burdened with "legal disability" that transferred their legal and property rights to the custody of their husbands. Such laws persisted until well into the twentieth century, and were manifestly constraining for women who participated in the marketplace on their own accord. At the same time, women were not as likely to acquire human capital or business training from formal schooling and outside apprenticeships. Under these circumstances, family businesses permitted women a wider sphere of economic activities and influence than they could otherwise have attained. As such, the prevalence of family firms rather than corporations need not signal "retardation" or failure to adjust to the

\footnotetext{
${ }^{57}$ Bertrand, Marianne, and Antoinette Schoar, "The Role of Family in Family Firms." Journal of Economic Perspectives, 20 (2) 2006: 73-96, at 95.
} 
needs of a market economy. Instead, different forms of business organization might offer appropriate solutions to the specific circumstances and needs of each society. 
Figure 1: Women Inventors and Total Patenting in France, 1800-1855

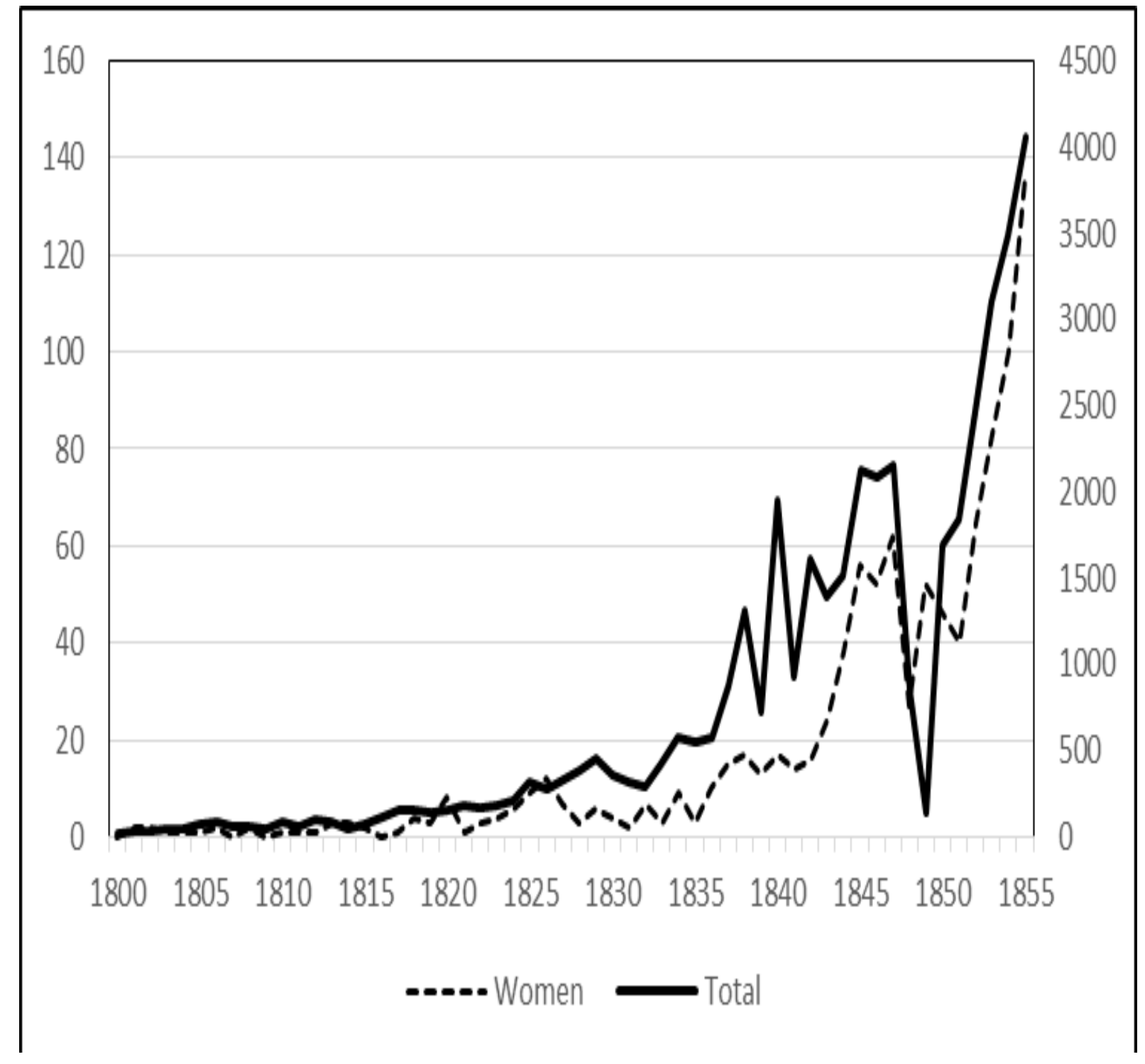

Sources: Institut national de propriété industrielle; France, Ministère de l'agriculture, Catalogue des brevets d'invention, d'importation et de perfectionnement, various years; and Federico, Pasquale J., "Historical Patent Statistics 1791 - 1961," in: Journal of the Patent Office Society v.46 (2) 1964: S. 89 - 171. 
Table 1: Characteristics of Patenting by Male and Female Inventors in France, 1791-1855

WOMEN

MEN

\section{Industry}

Agriculture

Patents Percent

Apparel

17

1.7

190

19.1

Chemicals/Medical

120

12.0

$76 \quad 7.6$

Machines/Transport

Food

103

10.3

178

17.8

Iron/Metals

Printing/Arts

Textiles

Miscellaneous

$44 \quad 4.4$

92
153

$153 \quad 15.3$

27

2.7

\section{Patent Term}

5 years

10

15

Addition

Patents Percent

$122 \quad 12.2$

$46 \quad 4.6$

$545 \quad 54.5$

$288 \quad 28.8$

\section{Occupation}

Professional

Business(wo)man

Manufacturer

Corset-maker

Teacher

Artisan/Worker

Engineer/Machinist

$\begin{array}{ll}\text { Patents } & \text { Percent } \\ 68 & 18.0 \\ 34 & 9.0 \\ 179 & 47.4 \\ 37 & 9.8 \\ 20 & 5.3 \\ 40 & 10.6 \\ 1 & 0.0\end{array}$

Patents Percent

$198 \quad 24.3$

$84 \quad 10.3$

$220 \quad 27.0$

-- $\quad-$

$15 \quad 1.8$

$156 \quad 18.9$

$142 \quad 17.4$

\section{Location}

Paris

Provinces

Foreign

$\begin{array}{ll}\text { Patents } & \text { Percent } \\ 789 & 78.8 \\ 167 & 16.7 \\ 45 & 4.5\end{array}$

Patents Percent

$562 \quad 51.3$

$\begin{array}{ll}437 & 39.9\end{array}$

$\begin{array}{ll}96 & 8.8\end{array}$ 
Sources: INPI, and France, Ministère de l'agriculture, Catalogue des brevets d'invention d'importation et de perfectionnement, various years.

Notes: Patents were categorized into the industry of final use. Each patent was assigned to a single inventor, even if the rights were shared with collaborators. The data for women include all patents through 1855 , whereas the patents filed by men comprise a random sample drawn from the years 1791-1840. 
Table 2: Patenting by French and American Women Inventors in the $19^{\text {th }}$ Century

Patents by

French Women

(1791-1855)
Patents by

U.S. Women

$(1790-1895)$

Multiple Patenting

One patent filed

Two or Three

Four to Nine

Ten or More

\section{Coinventors}

Female, Related

Male, Related

Female, Unrelated

Male, Unrelated

\section{Marital Status}

Single

Married

Widowed

$\begin{array}{llll}\text { Patents } & \text { Percent } & \text { Patents } & \text { Percent } \\ 368 & 36.8 & 2683 & 66.6 \\ 346 & 34.6 & 874 & 21.7 \\ 227 & 22.7 & 324 & 8.0 \\ 60 & 5.6 & 149 & 3.7\end{array}$

$\begin{array}{llll}\text { Patents } & \text { Percent } & \text { Patents } & \text { Percent } \\ 20 & 7.8 & 19 & 6.0 \\ 99 & 38.8 & 115 & 36.3 \\ 36 & 14.1 & 35 & 11.0 \\ 100 & 39.2 & 148 & 46.7\end{array}$

$\begin{array}{llll}\text { Patents } & \text { Percent } & \text { Patents } & \text { Percent } \\ 296 & 29.6 & 127 & 21.2 \\ 414 & 41.4 & 240 & 40.0 \\ 290 & 29.0 & 233 & 38.8\end{array}$

Sources: INPI, and France, Ministère de l'agriculture, Catalogue des brevets d'invention d'importation et de perfectionnement, various years. U.S. Patent Office, various years. Notes: The data for French women include all patents through 1855, whereas the patents filed by U.S. women cover the years 1790-1895. Coinventors' relationships were determined by whether the individuals had the same surname, which will tend to be an underestimate. Each patent/award was assigned to a single inventor, even if the rights were shared with collaborators. The number of patents per person were underestimated for later cohorts. 
Table 3: Binomial Regressions of Patenting by French Women, 1791-1855

Dependent Variable: Number of patents per person

\begin{tabular}{|c|c|c|c|c|}
\hline & Coeff. & Wald Chi-sq & Coeff. & $\begin{array}{l}\text { Wald } \\
\text { Chi-sq }\end{array}$ \\
\hline & - & & - & \\
\hline Intercept & 10.2618 & $3.19 *$ & 11.4356 & $4.09 * * *$ \\
\hline Paris residence & 0.4021 & $34.09 * * *$ & 0.4312 & $39.23 * * *$ \\
\hline Year & 0.0061 & $3.88 * *$ & 0.0068 & $4.97 * *$ \\
\hline Mfg enterprise & -0.1171 & 0.83 & -0.0202 & 0.03 \\
\hline $\begin{array}{l}\text { Mfg enterprise own } \\
\text { wife/widow }\end{array}$ & 0.9489 & $41.26 * * *$ & 0.7026 & $22.03 * * *$ \\
\hline Wife/widow & -0.3649 & $34.31 * * *$ & -0.3223 & $26.96 * * *$ \\
\hline Five-year patent & -0.494 & $23.02 * * *$ & -0.4228 & $17.2 * * *$ \\
\hline Industry & & & & \\
\hline Apparel & & & 0.0851 & 1.0 \\
\hline Food & & & -0.1199 & 1.36 \\
\hline Household & & & -0.0375 & 0.18 \\
\hline Textiles & & & -0.0872 & 0.9 \\
\hline Other & & & -0.4651 & $35.96 * * *$ \\
\hline - Log Likelihood & 1380.17 & & $1407.7^{* *}$ & \\
\hline $\begin{array}{l}\text {-Full Log Likelihood } \\
\quad \mathrm{N}=1004\end{array}$ & 2185.94 & & $2158.4^{* *}$ & \\
\hline
\end{tabular}

Sources: Institut national de propriete industrielle; France, Ministère de l'agriculture, Catalogue des brevets d'invention d'importation et de perfectionnement, various years.

Notes: The excluded variable for marital status is unmarried, and for industry exhibits that are in "untraditional" fields for women, such as engines, transportation, chemicals and heavy industries. A five-year patent is a cheaper patent that expires at the end of five years. 
Table 4

Exhibitors and Awards at the French Expositions, 1798-1855

\begin{tabular}{|c|c|c|c|c|c|}
\hline \multirow[b]{2}{*}{ Year } & \multirow{2}{*}{$\begin{array}{l}\text { Total No. } \\
\text { Exhibitors }\end{array}$} & \multicolumn{2}{|c|}{ TOTAL AWARDS } & \multicolumn{2}{|l|}{ WOMEN } \\
\hline & & No. Medals & No. Awards & $\%$ Medals & $\%$ Awards \\
\hline 1798 & 110 & 3 & 23 & 33.3 & 4.4 \\
\hline 1801 & 220 & 34 & 80 & 0.0 & 2.5 \\
\hline 1802 & 540 & 42 & 254 & 9.5 & 1.6 \\
\hline 1806 & 1422 & 131 & 610 & 4.6 & 2.9 \\
\hline 1819 & 1662 & 308 & 869 & 4.2 & 2.6 \\
\hline 1823 & 1648 & 475 & 1091 & 4.8 & 3.9 \\
\hline 1827 & 1795 & 425 & 1254 & 4.7 & 3.4 \\
\hline 1834 & 2447 & 708 & 1785 & 3.0 & 2.7 \\
\hline 1839 & 3381 & 868 & 2305 & 2.5 & 2.2 \\
\hline 1844 & 3958 & 1277 & 3253 & 3.4 & 1.3 \\
\hline 1849 & 4650 & 1652 & 3738 & 3.1 & 2.9 \\
\hline TOTAL & 21833 & 5923 & 15262 & 3.4 & 2.5 \\
\hline $1855^{*}$ & $10731 *$ & 6564 & 10564 & 1.0 & 0.8 \\
\hline
\end{tabular}

Sources: Rapport du jury central, Catalogues des Expositions des produits de l'industrie française, Paris: various years through 1849; Catalogue de 1'Exposition Universelle a Paris, 1855: Paris, 1856.

Notes: The total number of awards and exhibitors includes both men and women. Total awards comprise medals (gold, silver, and bronze) and citations or honourable mentions. The percentage shows the number of awards to women as a fraction of the total granted to all exhibitors in that year. *The total number of exhibitors for the 1855 Universal Exposition was 21,779, of which 10,731 were from France and its colonies. 
Table 5: Women's Participation in Industrial Expositions, by Marital Status, 1791-1855

\begin{tabular}{|c|c|c|c|c|}
\hline & $\begin{array}{c}\text { Single } \\
(\%)\end{array}$ & $\begin{array}{c}\text { Widow } \\
(\%)\end{array}$ & $\begin{array}{c}\text { Married } \\
(\%)\end{array}$ & $\begin{array}{c}\text { TOTAL } \\
(\%)\end{array}$ \\
\hline \multicolumn{5}{|l|}{ Industry } \\
\hline Apparel & 28.2 & 11.9 & 29.9 & 20.5 \\
\hline Arts & 16.4 & 16.3 & 14.5 & 14.5 \\
\hline Corsets & 4.5 & 1.1 & 12.2 & 5.4 \\
\hline Food & 2.7 & 4.7 & 1.8 & 3.3 \\
\hline Household & 19.1 & 12.6 & 15.8 & 14.1 \\
\hline Nontraditional & 3.6 & 18.1 & 9.5 & 11.6 \\
\hline Textiles & 25.5 & 33.2 & 14.5 & 28.7 \\
\hline Misc & 1 & 2.3 & 1.8 & 1.6 \\
\hline \multicolumn{5}{|l|}{ Occupation } \\
\hline Artisan & 17.4 & 7.7 & 16.7 & 12.2 \\
\hline Businesswoman & 2.2 & 7.1 & 8.8 & 6.9 \\
\hline Corset-maker & 6.5 & 0.6 & 9.6 & 5 \\
\hline Manufacturer & 73.9 & 78.9 & 57.9 & 70.5 \\
\hline Other & 0 & 5.8 & 7 & 3.5 \\
\hline \multicolumn{5}{|l|}{ Time } \\
\hline $1791-1834$ & 34.6 & 30 & 31.2 & 29.5 \\
\hline $1835-1844$ & 13.6 & 17.3 & 14 & 14.6 \\
\hline $1845-1850$ & 20 & 14.8 & 22.6 & 17.5 \\
\hline 1851-1855 & 31.8 & 37.9 & 32.1 & 38.4 \\
\hline \multicolumn{5}{|l|}{ Awards } \\
\hline None & 34.6 & 32.5 & 35.3 & 37.4 \\
\hline One & 38.2 & 29.6 & 40.3 & 33.3 \\
\hline Two & 15.4 & 19.9 & 17.6 & 17.2 \\
\hline More than two & 11.8 & 18.1 & 6.8 & 12.1 \\
\hline Collaborators & 27.3 & 31.8 & 11.3 & 22.3 \\
\hline Patentee & 17.3 & 20.1 & 22.7 & 19.3 \\
\hline Paris Residency & 59.1 & 51 & 67.2 & 54.8 \\
\hline TOTAL & $17.1 \%$ & $43.0 \%$ & $34.3 \%$ & $\mathrm{~N}=645$ \\
\hline
\end{tabular}

Sources: Rapport du jury central, Catalogues des expositions des produits de l'industrie française, Paris: various years through 1849; Catalogue de l'Exposition Universelle à Paris, 1855: Paris, 1856.

Notes: The table shows column percentages for 645 observations; totals may not sum to 100 because of missing values. The data include all women who obtained at least a citation by the juries for the expositions. "Nontraditional" fields for women comprise engines, transportation, chemicals and heavy industries. Patent holders were determined by matching the names of exhibitors to the records of the Institut national de propriété industrielle. 
Table 6

Binomial Regressions of Female Participation in Industrial Expositions, 1791-1855

Dependent Variable: Number of Times Awards Granted

\begin{tabular}{|c|c|c|c|c|}
\hline & \multicolumn{2}{|c|}{ (1) } & \multicolumn{2}{|c|}{ (2) } \\
\hline & Coeff. & Wald Chi-sq & Coeff. & Wald Chi-sq \\
\hline Intercept & 53.11 & $91.87^{* * *}$ & 53.6514 & $96.09 * * *$ \\
\hline Paris Residence & 0.14 & $2.68^{*}$ & 0.0817 & 0.83 \\
\hline Year & -0.03 & $92.50 * * *$ & -0.0292 & $95.74 * * *$ \\
\hline Wife/widow & -0.04 & 0.1 & -0.1373 & 1.16 \\
\hline \multicolumn{5}{|l|}{ Mfg firm owned by } \\
\hline \multicolumn{5}{|l|}{ Industry } \\
\hline Apparel & & & -0.3729 & $8.97 * * *$ \\
\hline Food & & & 0.3595 & 2.53 \\
\hline Household & & & -0.1831 & 1.62 \\
\hline Textiles & & & -0.2196 & $3.13^{*}$ \\
\hline Other & & & 0.0081 & 0.0 \\
\hline Patent holder & & & 0.5069 & $30.99 * * *$ \\
\hline -Log Likelihood & $457.4^{*}$ & & $428.8 * * *$ & \\
\hline \multirow[t]{2}{*}{-Full Log Likelihood } & $736.7^{*}$ & & $706.8^{* * *}$ & \\
\hline & $\mathrm{N}=6$ & & $\mathrm{~N}=645$ & \\
\hline
\end{tabular}

Sources: Rapport du jury central, Catalogues des Expositions des produits de l'industrie française, Paris: various years through 1849; Catalogue de 1'Exposition Universelle a Paris, 1855: Paris, 1856.

Notes: The data include all women who obtained at least a citation by the juries for the expositions. The excluded variable for marital status is unmarried. The excluded variable for industry comprises the "nontraditional" fields, such as engines, transportation, chemicals and heavy industries. Patent holders were determined by matching the names of exhibitors to the records of the Institut national de propriété industrielle. 


\section{BIBLIOGRAPHY}

Anderson, Bonnie S., A history of their own : women in Europe from prehistory to the present New York : Oxford University Press, 2000.

Beachy, Robert, Beatrice Craig and Alastair Owens, eds., Women, business and finance in nineteenthcentury Europe: rethinking separate spheres, Oxford and New York: Berg, 2006.

Benoit, Serge et al. (eds), Encourager l'innovation en France et en Europe, Paris: CTHS, 2007.

Bertrand, Marianne, and Antoinette Schoar, "The Role of Family in Family Firms." Journal of Economic Perspectives 20 (2) 2006: 73-96.

Bessière, Céline, "Female and male domestic partners in wine-grape farms (Cognac, France): conjugal asymmetry and gender discrimination in family businesses," History of the Family, Vol. 19 Issue 32014 : 341-357.

Blanc, Étienne, Traité de la contrefaçon en tous genres et de sa poursuite en justice, Paris: H. Plon, 1855.

Bulletin des lois de la République Française, various years.

Carter, Edward et al. (editors), Enterprise and Entrepreneurs in Nineteenth- and Twentieth-Century France. Baltimore: Johns Hopkins University Press. 1976.

Catalogue Officiel, Exposition des Produits de L'industrie de Toutes les Nations, 1855, 2e edition, Paris, E. Panis, 1856.

Chanteux, Anne, «Les inventives. Femmes, inventions et brevets en France à la fin du XIXe siècle », Documents pour l'histoire des techniques [En ligne], $17 \mid$ 1er semestre 2009, mis en ligne le 28 décembre 2010, consulté le 14 octobre 2014. URL : http://dht.revues.org/519

Clark, Linda L., The rise of professional women in France gender and public administration since 1830, Cambridge, UK ; New York, NY : Cambridge University Press, 2000.

Collins, James B. "The economic role of women in seventeenth-century France." French historical studies (1989): 436-470.

De Colmont, Achille, Histoire des Expositions des Produits de l'Industrie Français, Paris: Guillaumin, 1855.

Cordato, Mary Frances, Representing the Expansion of Woman's Sphere: Women's Work and Culture at the World's Fairs of 1876, 1893, and 1904. New York University, 1989.

Cowan, Ruth Schwartz, "From Virginia Dare to Virginia Slims: women and technology in American life." Technology and Culture (1979): 51-63.

Crossick, Geoffrey and Heinz-Gerhard Haupt, The Petite Bourgeoisie in Europe 1780-1914: Enterprise, Family and Independence, New York: Routledge, 1995. 
Bessière, Céline, "Female and male domestic partners in wine-grape farms (Cognac, France): conjugal asymmetry and gender discrimination in family businesses," History of the Family, Vol. 19 Issue 32014 : 341-357.

Craig, Beatrice, "Petites bourgeoises and penny capitalists: women in retail in the Lille area during the nineteenth century," Enterprise and Society, vol. 2 (2) 2001:198-224.

Crowston, Clare Haru, Fabricating women: the seamstresses of Old Regime France, 1675-1791, Durham, NC : Duke University Press, 2001.

Cucculelli, Marco \& Micucci, Giacinto, 2008.

"Family succession and firm performance: Evidence from Italian family firms," Journal of Corporate Finance, Elsevier, vol. 14(1), pages 17-31, February.

Davidoff, Leonore, and Catherine Hall. Family fortunes: Men and women of the English middle class 1780-1850, London: Routledge, 2002.

De Neuville, A., "Le genie de l'invention chez les femmes," La Revue mondiale: ancienne Revue des revues, 1900, 184-190.

Daumalin, Xavier and Henri Tachoire, "Un couple d'innovateurs marseillais et la Société d'encouragement pour l'industrie nationale : les époux Degrand-Gurgey," in Benoit, Serge et al. (eds), Encourage l'innovation en France et en Europe, Paris: CTHS, 2007: 123-140.

Dermineur, Elise, "Single Women and the Rural Credit Market in Eighteenth-Century France," Journal of Social History, 48 (1) 2014.

Dictionnaire chronologique et raisonné des descouvertes en France, de 1789 à 1820, 1824.

Saul Estrin and Tomasz Mickiewicz, Female Entrepreneurship in Developed and Developing Economies, Small Business Economics, Vol. 37, No. 4, (November 2011), pp. 397-415.

Galvez-Behar, Gabriel, La République des inventeurs. Propriété et organisation de l'invention en France, 1791-1922, Presses universitaires de Rennes, 2008.

Kindleberger, Charles P., Economic Growth in France and Britain, 1851-1950, Harvard University Press, 1964.

Foreman-Peck, James et al., "Entrepreneurs and business performance in nineteenth century France," European Review of Economic History, vol. 2 (3) 1998: 235-262.

Goldin, Claudia, "The Economic Status of Women in the Early Republic: Quantitative Evidence," Journal of Interdisciplinary History 16 (1986): 377-93.

Grantham G., "Occupational, Marital, and Life-Cycle Determinants of Women's Labor Force Participation in Mid-Nineteenth-Century Rural France," Feminist Economics, 18(4) 2012: 97-119.

Green, David R. and Alastair Owens, "Gentlewomanly Capitalism? Spinsters, Widows, and Wealth Holding in England and Wales, c. 1800-1860," Economic History Review, Vol. 56, No. 3 (2003): 510536. 
Cruz, Laura, and Mokyr, Joel, eds. Volume 2 : Birth of Modern Europe : Culture and Economy, 14001800: Essays in Honor of Jan de Vries : Culture and Economy, 1400-1800.

Hardwick, Julie. "Seeking separations: gender, marriages, and household economies in early modern France." French historical studies (1998): 157-180.

Hardwick, Julie, Family business: litigation and the political economies of daily life in early modern France, Oxford [UK] ; New York : Oxford University Press, 2009.

Hardwick, Julie. "Women "Working" the Law: Gender, Authority, and Legal Process in Early Modern France." Journal of Women's History 9, no. 3 (1997): 28-49.

Hilaire-Perez, Liliane. "Technical Invention and Institutional Credit in France and Britain in the 18th Century." History \& Technology, 16 (3) 2000: 285.

Hilaire-Perez, Liliane, L’invention technique au siècle des Lumières, Paris: Albin Michel, 2000.

Hoffman, Philip T., Gilles Postel-Vinay and Jean-Laurent Rosenthal, "Private Credit Markets in Paris, 1690-1840," Journal of Economic History, vol. 52 (2) 1992: 293-306.

Hoffman, Philip T., Gilles Postel-Vinay, et Jean-Laurent Rosenthal. Priceless Markets: The Political Economy of Credit in Paris, 1660-1870. University of Chicago Press, 2001.

Hufton, Olwen. "Women and the family economy in eighteenth-century France." French Historical Studies (1975): 1-22.

Hunt, Jennifer, et al. "Why are women underrepresented amongst patentees?" Research Policy 42.4 (2013): 831-843.

Kay, Alison C., The foundations of female entrepreneurship: enterprise, home and household in London, c. 1800-1870, London: Routledge, 2009.

Khan, B. Zorina, The Democratization of Invention: Patents and Copyrights in American Economic Development. NBER and Cambridge University Press (2005).

Khan, B. Zorina, "Going for Gold: Industrial Fairs and Innovation in the Nineteenth-Century United States," Special Issue on Innovation without Patents, Revue Economique, vol. 64 (1) 2013: 89-114.

Khan, B. Zorina. "Married women's property laws and female commercial activity: Evidence from United States Patent Records, 1790-1895." The Journal of Economic History 56 (2) 1996: 356-388.

Khan, B. Zorina. "“Not for Ornament": Patenting Activity by Nineteenth-Century Women Inventors." Journal of Interdisciplinary History 31 (2) 2000: 159-195.

Khan, B. Zorina and Kenneth L. Sokoloff, "'Schemes of Practical Utility': Entrepreneurship and Innovation among 'Great Inventors' During Early American Industrialization, 1790-1865," Journal of Economic History, vol. 53 (2) 1993: 289-307.

Kuisel, Richard F., Capitalism and the State in Modern France, Cambridge: Cambridge University Press, 1981. 
James, Harold, Family Capitalism: Wendels, Haniels, Falcks, and the Continental European Model, Cambridge : Harvard University Press, 2006.

Labardin, Pierre, Epouses et petites entreprises, Revue Française de Gestion, vol. 38, 2008, pp.97-117.

Lanza, Janine Marie, From wives to widows in early modern Paris gender, economy, and law Aldershot, England ; Burlington, VT : Ashgate, c2007.

Lamoreaux, Naomi, Insider Lending: Banks, Personal Connections, and Economic Development in Industrial New England, Cambridge and New York: Cambridge University Press, 1996.

Lamoreaux, Naomi R. and Jean-Laurent Rosenthal, Legal Regime and Contractual Flexibility: A Comparison of Businesse's Organizational Choices in France and the United States during the Era of Industrialization, American Law and Economics Review, Vol. 7, No. 1, Special Issue on Comparative Law (Spring 2005), pp. 28-61.

Levasseur, Emile, Histoire des classes ouvrières et de l'industrie en France avant 1789, Volume 2, Paris: A. Rousseau, 1901,

Martin, Morag, "Entrepreneur or charlatan? The commerce of cosmetics, patents and the medical profession in France 1750-1830," in Les chemins de la nouveauté: innover, inventer au regard de l'histoire, eds. Liliane Hilaire-Pérez and Anne-Françoise Garçon (Paris: Éditions du CTHS, 2003).

McGaw, Judith A. "Women and the history of American technology." Signs (1982): 798-828.

McMillan, James F., France and women, 1789-1914: gender, society and politics, London : Routledge, 2000.

Nicholas, Tom. "Clogs to Clogs in Three Generations? Explaining Entrepreneurial Performance in Britain Since 1850," Journal of Economic History (September 1999): 688-713.

Nye, John Vincent. "Firm size and economic backwardness: A new look at the French industrialization debate." The Journal of Economic History 47.03 (1987): 649-669.

This article challenges the traditional view of French industry - that small, inefficient family firms retarded France's economic growth - by examining data for the French textile and flour milling industries taken from the industry census of 1861-1865. The evidence suggests that the average size of French firms suited the economic and technological conditions of the day. The industries studied exhibit constant returns to scale over a wide output range. France would not seem likely to have gained much from larger firms. This is consistent with revisionist contentions that French industry was as rational as that of other nations.

Yihui Pan, Tracy Yue Wang, Michael S.,Weisbach, Does Uncertainty about Management Affect Firms' Costs of Borrowing? NBER Working Paper \#20674, 2014.

Francisco Pérez-González, "Inherited Control and Firm Performance," American Economic Review, vol. 96 (5) 2006: 1559-1588.

Perpigna, Antoine, Manuel des inventeurs et des brevetés (8e édition), Paris: A. Perpigna, 1852.

Phillips, Nicola J., Women in Business, 1700-1850, Boydell \& Brewer, 2006. 
Redondi, Pietro, Nation et Entreprise : la Société d'encouragement pour l'industrie nationale, 1801-1818, History and Technology, vol. 5, 1988:193-222.

Renouard, Augustin-Charles, Traité des brevets d'invention (3e édition revue et augmentée, Paris: Guillaumin, 1865.

Riboud, M., "An analysis of women's labor force participation in France: cross-section estimates and time-series evidence." Journal of Labor Economics 3 (1) 1985: S177-200.

Scott, Joan W., and Louise A. Tilly. "Women's work and the family in nineteenth-century Europe." Comparative Studies in Society and History 17.01 (1975): 36-64.

Sheridan, Geraldine. "Women in the Booktrade in Eighteenth-Century France." Journal for Eighteenth-Century Studies 15.1 (1992): 51-70.

Smith, Michael S., The Emergence of Modern Business Enterprise in France, 1800-1930, Cambridge: Harvard University Press, 2006.

Smith, Michael S. "Putting France in Chandlerian Framework: France's 100 Largest Industrial Firms in 1913." Business History Review 72, no. 1 (Spring98 1998): 46.

Stetson, Dorothy McBride, Women's Rights in France, Westport, CT : Greenwood, 1987.

Thompson, Victoria, The Virtuous Marketplace: Women and Men, Money and Politics in Paris, 18301870. Baltimore, 2000. 